Tanja Milić

University of Belgrade, Faculty of Organizational Sciences, Serbia

\title{
Doing Business in Serbia: Key Corporate Stakeholders
}

DOI: 10.7595/management.fon.2021.0019

\begin{abstract}
:
Research Question: The aim of this empirical research paper is to determine key corporate stakeholders in the Republic of Serbia. Motivation: Serbia belongs to the group of emerging economies striving to adopt market economy management practices. Stakeholders occupy an important position in the strategic business planning process. So far, research on corporate stakeholders in Serbia is scarce, and does not provide enough data on this, for strategic business planning and strategic management, important topic. Hence, the motivation for such a study determining the significance and role of certain corporate stakeholder groups for companies operating in Serbia has arisen. Investigating this issue can show, and thus help Serbian managers, how to improve and/or redirect their strategic business decisions, and subjects they are aimed at, thus increasing the potential for making better strategic business plans, developing better business strategies, which will secure better business performance results. Idea: The idea of the research is to examine the perceptions and attitudes of managers of business organizations operating in the Republic of Serbia in relation to selected relevant corporate stakeholder groups, and using investigated perceptions and attitudes of managers to evaluate the degree of significance and impact of selected relevant corporate stakeholders in the business life of the Republic of Serbia. Data: Empirical research was conducted on a sample of 107 respondents, managers of business organizations operating in the territory of the Republic of Serbia, randomly selected from publicly available databases of business organizations, public associations and media in Serbia, using Computer Assisted Web Interview - CAWI technique. Tools: Analysis of the data was conducted in SPSS v20.0 statistical tool. Data analysis in this study consisted of descriptive statistics. Univariate analysis was used through the analysis of frequency tables and individual ranking statistics. Nonparametric Kruskal-Wallis and post hoc Mann Whitney $U$ test were used to test the significance of differences. Findings: Findings of the research have shown that, respectively, customers and owners hold leading positions among surveyed corporate stakeholders in Serbia, successively followed by suppliers, managers, government institutions, employees, investors, distributors, competitors, community as a whole, media, local community, vulnerable groups, and, lastly, with the lowest significance, NGOs. Service organizations proved to be the most sensitive to corporate stakeholders issue, and commercial organizations the least. Contribution: The main contribution of this paper is a systematic analysis of the stakeholder issue, and quantitative key corporate stakeholder identification in the Republic of Serbia.
\end{abstract}

Keywords: key corporate stakeholders, Republic of Serbia, strategic business planning, strategic management, business performance, emerging economy

JEL Classification M21, M31

\section{Introduction}

The Republic of Serbia belongs to the group of emerging economies striving to adopt market economy management practices. Stakeholders occupy an important position in the strategic business planning process. According to Evan and Freeman (1993), stakeholders are classified as certain groups that provide value to business operations, and are vital to the survival and success of an organization. These are individuals and groups that are interested in the organization, that is, in the success of its business. They have certain requirements towards the organization, which are different, or even conflicting. Satisfying expectations, and incorporating stakeholder values are important management task as well as part of corporate so- 
cial and economic responsibility (Digman, 1990). Stakeholders are also defined as groups or individuals who can influence or are influenced by an organization. They are interested in the nature of the company's business, directions of its development, and its competitive position. A stakeholder group can be defined as a collective of two or more individuals, who perceive, and evaluate themselves on the basis of shared norms, values, and goals in the context of a socio-economic issue (Schneider \& Sachs, 2017). Stakeholders can be classified into three groups: (1) internal stakeholders: owners, decision makers, unions and employees; (2) stakeholders appearing on the market: customers, suppliers, competitors; and (3) external stakeholders: government, financial institutions, political groups, trade associations (Griffin \& Ebert, 1993). Individual stakeholders play different roles in the survival and success of a business (Phillips, Freeman \& Wicks, 2003; Phillips, 1997; Evan \& Freeman, 1993). Orientation towards stakeholders implies that within the strategic analysis, aspirations of internal and external stakeholders are considered and also the way in which they can affect the future strategic position of the company (Milicevic, 2014).

So far research on corporate stakeholders in Serbia is scarce, and does not provide enough data on this, for strategic business planning and strategic management, important topic. Investigating this issue can show, and hence help Serbian managers, how to improve, and/or redirect their strategic business decisions, and subjects they are aimed at, thus increasing the potential for making better strategic business plans, developing better business strategies, which will secure better business performance results.

The paper is organized as follows. After the introduction part, an overview of the scientific and professional literature is given, followed by a description of the research with an analysis of results. Concluding remarks are provided at the end of the paper.

\section{Literature Review}

Besides the general requirement that organizations should run their operations in the most economical, efficient, and effective manner possible to increase performance, today, there is an increasing pressure for organizations to run their operations with their stakeholders in mind (Khomba, Kanguade-Ulaya \& Hanif, 2013; Metcalf \& Benn, 2012). Being interested groups that have different stakes in company affairs, stakeholders need management's attention that is to be incorporated in the corporate planning, and performance measurement systems (Prozesky, 2010). The stakeholder theory was introduced to the strategic management field to address the organizational challenges of an increasingly interconnected and globalized society (Schneider \& Sachs, 2017). In his very popular book, Freeman (1984) argued that the predominating logic of profit maximization could no longer support the complexity of the contemporary business world. The development of, and emphasis on the stakeholder-centered approach that is grounded on the stakeholder theory is a result of visible shortcomings of the shareholder-centered approach, which tends to overemphasize the importance of shareholders as sole owners of any business entity, and in the process ignore significant roles that other stakeholders play in the sustainability of any business (Khomba et al., 2013). Besides shareholders, there are other stakeholders, such as customers, suppliers, employees, local communities, and the environment, which all have dual roles and act as instrumental towards provisions of inputs to companies, and also the consumption of companies' products (Prozesky, 2010). Proponents of the stakeholder approach to management argue that such an approach is justified in the sence that distribution in the company is done towards all of those who create value (Stovall, Neill, \& Perkins, 2004). The stakeholder-centered approach to stakeholder management appears as a fair recognition to other stakeholders, because they provide resources, and receive benefits from the corporation (Stovall et al., 2004). However, proponents of the mainstream shareholder-centered approach to corporate governance base their argument on the private property rights paradigm (Stovall et al., 2004), which implies that, as risk-taking owners and providers of financial capital, shareholders tend to prefer to promote their own interests over those of other stakeholders. In its essence, it is contended that as primary owners of business, shareholders should hold the management team responsible for achieving the primary business goal in the form of maximizing shareholder wealth.

The stakeholder approach is different from other strategic management theories in the part that it sees value creation as embedded in the relationships between organization and its stakeholders (Freeman et al., 2010; Post et al., 2002). The idea of the stakeholder theory lies in the belief that the purpose of an organization is to create as much value as possible for all of its stakeholders, whereby the integration of relevant stakeholder interests into the organizational value creation processes accounts for the business challenges in a society (Freeman et al., 2010).

The stakeholder theory grew to become one of the main management frameworks today, up to the point of having been described as a management theory of the 21 st century suitable for understanding and redefining the role of business and value creation in society (Freeman et al., 2010). 
The stakeholder theory has served to analyse and understand multiple phenomena in various fields of the organisational sciences, such as strategic management (Strand \& Freeman, 2015; Haksever et al., 2004; Freeman, 1984), international business (Lehtimaki \& Kujala, 2015), business ethics (Purnell \& Freeman, 2012; Phillips, 1997) and corporate responsibility (Sachs \& Maurer, 2009; Strand et al., 2015; Brower \& Mahajan, 2013).

The extant stakeholder theory research focuses on topics such as the identification of stakeholders, the evaluation of stakeholder legitimacy and claims, the role of business in society, and the taxonomy of stakeholder theories (Scherer \& Patzer, 2011).

In Serbia, a majority of researchers emphasize the need for managers to know methods of identifying (Jovanovic, Milenkovic \& Dumonjic, 2017; Losonc, 1997) and managing stakeholders, but with previously clearly defined priorities (Krstic \& Trbovic, 2015; Krstic, 2014; Petrovic, 2012; Nikolic \& Eric, 2011; Vujovic, Stefanovic \& Vucurevic, 2009), link the importance of stakeholders with company performance in tourism (Vujicic, 2019; Kicosev, Radosavljevic, Kovacev \& Djukic, 2011) and culture (Terzic, 2016; Jovanovic, 2012), and especially emphasize the stakeholder role in the process of adopting corporate social responsibility practices (Culafic, 2015; Rodic, 2012; Figar \& Figar, 2011; Kontic \& Kontic, 2010; Predic, 2009; Babic, 2007), as well as in the issue of corporate communications and reputation (Krstic, 2014; Mitic, 2013; Djordjevic, 2010; Popovic, 2010). Jovanovic \& Delibasic (2014) have for the first time implemented the integrated QFD and fuzzy AHP approaches in the selection of supplier in one Serbian company, translating stakeholder needs into evaluating criteria for suppliers, and prioritizing stakeholders, stakeholders' requirements, evaluating criteria and, finally, prioritizing suppliers.

In the previous scientific research of corporate stakeholders in the Republic of Serbia, there is not a single paper that considers the relationship between the importance of individual groups of stakeholders from the aspect of managers operating in the Republic of Serbia. The elementary fact is that, both from the theoretical and practical aspects, this area is not yet sufficiently explored and applied. The lag in practice follows poor historical base and incomplete research. In domestic academic circles, the corporate stakeholders issue has not encountered particularly detailed elaborations. Literature in this domain is scarce, and it comes down to only a few articles that deal with this topic in a non-comprehensive way. Currently, a total of 70 electronically available scientific and professional papers containing the stakeholder as a key word have been published in the Republic of Serbia, but only 22 of them deal with stakeholders as the main topic. However, on the positive side, there are numerous papers dealing with individual groups of stakeholders from different points of view (Table 1.).

Table 1: Number of scientific papers published in Serbia per individual stakeholder keyword (SCIndeks Database)

\begin{tabular}{|l|c|}
\hline \multicolumn{1}{|c|}{ Keyword } & Number of papers published in Serbia \\
\hline Customer & 685 \\
Buyer & 151 \\
Consumer & 1,066 \\
Supplier & 104 \\
Media & 2,040 \\
Investors & 214 \\
Employees & 1,487 \\
Distributors & 37 \\
Managers & 1,011 \\
Owners & 416 \\
Competitors & 256 \\
Government institutions & 287 \\
Vulnerable groups & 83 \\
Local community & 334 \\
Community as a whole & 173 \\
NGOs & 28 \\
Nongovernment organization & 21 \\
\hline
\end{tabular}

But, this is still insufficient for full understanding of the mutual significance and relationships of individual stakeholder groups, which is a neccessary precondition for directing managers how to prioritize among actual corporate stakeholder groups in the Republic of Serbia helping them to improve, and/or redirect their strategic business decisions, and gain better business performance results. 


\section{Research Method}

In order to identify key corporate stakeholders in the Serbian economy, an empirical study was conducted. The research was based on the application of data collection methods from primary sources. The research was organized respecting the principles of the methodology of scientific research by Mihailovic (2012).

\subsection{Research purpose and research questions}

The purpose of the research is examining perceptions and attitudes of managers of business organizations operating in the Republic of Serbia in relation to selected relevant corporate stakeholder groups and using investigated perceptions and attitudes of managers to evaluate the degree of significance and impact of selected relevant corporate stakeholders in the business life of the Republic of Serbia.

In order to fulfill the purpose of research, in this regard, fundamentally, the research had defined the following subject of the survey: identifying and measuring attitudes of managers of businesses operating in the Republic of Serbia about selected relevant corporate stakeholders and the influence of selected relevant corporate stakeholders in the business life in the Republic of Serbia.

As defined, research objective is to determine the degree of significance of selected relevant corporate stakeholders for managers of business organizations operating in the Republic of Serbia.

The research is expected to lead to an answer to the following research question: to what extent selected relevant corporate stakeholders have an impact in the business life in the Republic of Serbia.

\subsection{Research participants}

Participants in the study were managers of business organizations operating in the territory of the Republic of Serbia. The survey was conducted on a sample of 107 respondents. Testing managers of business organizations has been conducted using quantitative research techniques via the Internet (Computer Assisted Web Interview - CAWI) with previous consent from each subject for participation in the study. As a sample frame, publicly available databases of business organizations, public associations and media in Serbia are used.

\subsection{Research instrument}

As a research tool for implementation of the method of collecting data from the primary sources the questionnaire was used, established on the basis of review of the scientific and expert literature and as recommended by Mihailovic (2012), and in compliance with special needs of research. After demographic characteristics of respondents and data about the organization, the questionnaire contained questions pertaining to selected relevant corporate stakeholders. The results of Cronbach's alpha test of questionnaire as a measure of its reliability indicate the consistent reliability of results obtained $(\alpha>0.7)$ (Cohen, Manion \& Morrison, 2007).

\subsection{Research model}

The research model is based on examining perceptions and attitudes of managers of business organizations operating in the Republic of Serbia in relation to selected relevant corporate stakeholder groups, from the standpoint of economy as a whole, and by economy sectors.

\subsection{Data analysis}

Items of the final questionnaire were analyzed using the SPSS v20.0 statistical tool. Data analysis in this study consisted of descriptive statistics. Univariate analysis was used through the analysis of frequency tables and individual ranking statistics. Nonparametric Kruskal-Wallis test, and post hoc Mann Whitney $U$ test were used to test the significance of differences. In the study, results with $p<0.1$ were declared significant (Kim, 2020; Kim \& Choi, 2019; Wasserstein \& Lazar, 2016; Mudge, Baker, Edge \& Houlahan, 2012). 


\section{Research Results}

4.1 Evaluation of the importance of selected corporate stakeholder groups for managers of business organizations operating in the Republic of Serbia

Research results of the importance of examined stakeholder groups for managers of business organizations operating in the Republic of Serbia are shown in Table 2.

Table 2: Statistical summary of univariate analysis of the importance of selected stakeholder groups for managers in the Republic of Serbia

\begin{tabular}{|c|c|c|c|c|c|c|c|c|c|}
\hline \multirow{2}{*}{$\begin{array}{l}\text { Stakeholder } \\
\text { group }\end{array}$} & \multicolumn{8}{|c|}{$\begin{array}{c}\text { Ranking scale (\%) } \\
1 \text { - Min, } 7 \text { - Max }\end{array}$} & \multirow{2}{*}{$\begin{array}{c}\text { Mean } \\
(\mu)\end{array}$} \\
\hline & 1 & 2 & 3 & 4 & 5 & 6 & 7 & Total & \\
\hline Customers & .0 & 1.0 & 2.9 & 8.7 & 7.8 & 31.1 & 48.5 & 100.0 & 6.11 \\
\hline Suppliers & 1.9 & 4.8 & 6.7 & 11.5 & 23.1 & 33.7 & 18.3 & 100.0 & 5.23 \\
\hline Media & 4.9 & 17.5 & 12.6 & 18.4 & 15.5 & 17.5 & 13.6 & 100.0 & 4.29 \\
\hline Investors & 4.1 & 8.2 & 12.2 & 16.3 & 12.2 & 26.5 & 20.4 & 100.0 & 4.86 \\
\hline Employees & .0 & 5.6 & 11.2 & 19.6 & 17.8 & 27.1 & 18.7 & 100.0 & 5.06 \\
\hline Distributors & 4.0 & 4.0 & 12.9 & 21.8 & 20.8 & 21.8 & 14.9 & 100.0 & 4.76 \\
\hline Managers & .0 & 3.8 & 9.7 & 12.5 & 31.8 & 27.9 & 14.4 & 100.0 & 5.13 \\
\hline Owners & 1.0 & 1.9 & 4.8 & 9.5 & 14.3 & 30.5 & 38.2 & 100.0 & 5.78 \\
\hline Competitors & 2.0 & 6.9 & 14.7 & 15.7 & 31.4 & 21.6 & 7.8 & 100.0 & 4.64 \\
\hline $\begin{array}{l}\text { Government } \\
\text { institutions }\end{array}$ & .9 & 8.4 & 12.1 & 10.3 & 17.7 & 27.0 & 23.4 & 100.0 & 5.10 \\
\hline $\begin{array}{l}\text { Vulnerable } \\
\text { groups }\end{array}$ & 4.9 & 14.7 & 17.6 & 25.5 & 19.6 & 6.9 & 10.8 & 100.0 & 4.04 \\
\hline $\begin{array}{l}\text { Local } \\
\text { community }\end{array}$ & 3.9 & 10.7 & 16.5 & 30.1 & 15.6 & 10.7 & 12.6 & 100.0 & 4.25 \\
\hline $\begin{array}{l}\text { Community as } \\
\text { a whole }\end{array}$ & 3.8 & 11.3 & 15.1 & 22.6 & 21.7 & 12.3 & 13.2 & 100.0 & 4.37 \\
\hline NGOs & 28.4 & 20.9 & 17.9 & 19.4 & 6.0 & 4.5 & 3.0 & 100.0 & 2.79 \\
\hline
\end{tabular}

From the fourteen corporate stakeholder groups surveyed during the study, findings have revealed that most managers of business organizations operating in the Republic of Serbia recognise the crucial roles that different stakeholders play for the success and sustainability of their operations. Such stakeholders include respectively observing customers, owners, suppliers, managers, government institutions, and employees. Though above average, the study findings reveal that the recognition of investors, distributors, competitors, community as a whole, media, local community, and vulnerable groups as organisational stakeholders successively received lower rankings. The lowest significance was assigned to NGOs, which received rankings below average. There is a clear research indication that managers in the Republic of Serbia primarily keep interests of those stakeholder groups that are primarily and directly linked to the value chain and essential business processes leading to service and product production and their sales on the market, gaining income and profit, and without which business operations would be seized. The less certain stakeholder group is linked to essential business process, the less importance it has.

\subsection{Evaluation of the influence of economy sector on corporate stakeholder importance for managers in the Republic of Serbia}

In order to determine key corporate stakeholders per economy sectors in the Republic of Serbia, the investigation of the influence of certain economy sectors, such as manufacturing, commercial, and service on the perception of corporate stakeholders is performed. The nonparametric Kruskal-Wallis and post hoc Mann Whitney $U$ test were used to examine the significance of differences. Results with $p<0.1$ were declared significant (Table 3.). 
Table 3: Economy sector impact on stakeholder group importance

\begin{tabular}{|c|c|c|c|c|}
\hline \multirow[b]{2}{*}{ Stakeholder group } & \multicolumn{3}{|c|}{$\begin{array}{c}\text { Economy sector } \\
\text { Rank }\end{array}$} & \multirow[b]{2}{*}{ p } \\
\hline & $\begin{array}{c}\text { Manufacturing } \\
\text { organization } \\
\left(x_{1}\right)\end{array}$ & $\begin{array}{c}\text { Commercial } \\
\text { organization } \\
\left(x_{2}\right)\end{array}$ & $\begin{array}{c}\text { Service } \\
\text { organization } \\
\left(x_{3}\right)\end{array}$ & \\
\hline Customers & 1938.0 & 1050.5 & 2162.5 & 0.43 \\
\hline Suppliers & 2213 & 1024.5 & 1913.5 & 0.6065 \\
\hline Media & 1630 & 1015 & 2405 & 0.00655 \\
\hline Investors & 1873.5 & 993 & 1693.5 & 0.7348 \\
\hline Employees & 2343 & 1001.5 & 2115.5 & 0.3201 \\
\hline Distributors & 2154.5 & 896 & 1800.5 & 0.3214 \\
\hline Managers & 2255.5 & 1112 & 1885.5 & 0.5741 \\
\hline Owners & 2175.5 & 1211 & 1969.5 & 0.7149 \\
\hline Competitors & 2112 & 934.5 & 2003.5 & 0.5371 \\
\hline Government institutions & 2071 & 1192.5 & 2092.5 & 0.8882 \\
\hline Vulnerable groups & 2000.5 & 810. & 2040.5 & 0.04465 \\
\hline Local community & 2088 & 782.5 & 1980.5 & 0.1754 \\
\hline Community as a whole & 2104.5 & 964 & 2184.5 & 0.07965 \\
\hline NGOs & 741.5 & 307.5 & 904 & 0.4253 \\
\hline
\end{tabular}

In relation to the importance of selected corporate stakeholders for managers of business organizations operating in the Republic of Serbia, it was examined whether there are statistically significant differences between respondents coming from three determined economy sectors: manufacturing, commercial, and service. Results reveal that respondents from service sector comparing to respondents from manufacturing, or commercial sector, attach more importance to the following corporate stakeholder groups: media (1630 vs. 1015 vs. $2405 ; p<0.05)$, vulnerable groups ( 2000.5 vs. 810 . vs. $2040.5 ; p<0.05)$, and community as a whole $(2104.5$ vs. 964 vs. $2184.5 ; p<0.1)$. Also, from the same data can be seen that manufacturing sector attaches more importance to the same previously mentioned groups of stakeholders comparing to service sector. For all other investigated corporate stakeholders, no statistically significant differences were found $(p>0.1)$.

For statistically significant stakeholder groups, multiple comparisons were performed using the Kruskal-Wallis test of any pair of economy sectors. In this case, the test was identical to the Mann Whitney $U$ test with normal approximation. Again, results with $p<0.1$ were declared significant (Table 4.).

Table 4: Multiple comparisons of economy sectors per statistically significant stakeholder groups

\begin{tabular}{|c|c|c|c|c|}
\hline \multicolumn{5}{|c|}{ Stakeholder group: Media } \\
\hline Pair & Difference & H statistic & Critical value & p-value \\
\hline $\mathrm{x}_{1}-\mathrm{X}_{2}$ & 0 & 0.5486 & 4.5287 & 0.4589 \\
\hline$x_{1}-x_{3}$ & 2 & 8.6923 & 4.5287 & 0.003195 \\
\hline $\mathrm{x}_{2}-\mathrm{X}_{3}$ & 2 & 4.8703 & 4.5287 & 0.02732 \\
\hline \multicolumn{5}{|c|}{ Stakeholder group: Vulnerable groups } \\
\hline Pair & Difference & H statistic & Critical value & p-value \\
\hline$x_{1}-x_{2}$ & 1 & 4.8508 & 4.5287 & 0.02763 \\
\hline$x_{1}-x_{3}$ & 0 & 0.5882 & 4.5287 & 0.4431 \\
\hline $\mathrm{x}_{2}-\mathrm{X}_{3}$ & 1 & 4.7176 & 4.5287 & 0.02986 \\
\hline \multicolumn{5}{|c|}{ Stakeholder group: Community as a whole } \\
\hline Pair & Difference & H statistic & Critical value & p-value \\
\hline$x_{1}-X_{2}$ & 0 & 1.2942 & 4.5287 & 0.2553 \\
\hline$x_{1}-x_{3}$ & 1 & 1.9495 & 4.5287 & 0.1626 \\
\hline$x_{2}-x_{3}$ & 1 & 4.5979 & 4.5287 & 0.03201 \\
\hline
\end{tabular}

In relation to media, statistically significant differences were found in two pairs of economy sectors: (1) manufacturing and service sector $(p<0.01)$, and $(2)$ commercial and service sector $(p<0.05)$. In the manufacturing and commercial sector pair no statistically significant difference was found $(p>0.1)$.

In relation to vulnerable groups, statistically significant differences were found in two pairs of economy sectors: (1) manufacturing and commercial sector $(p<0.05)$, and (2) commercial and service sector $(p<0.05)$. In the manufacturing and service sector pair no statistically significant difference was found $(p>0.1)$. 
In relation to the community as a whole, statistically significant difference was found in one pair of economy sectors: commercial and service sector $(p<0.05)$. In the other two pairs of economy sectors: (1) manufacturing and commercial sector, and (2) manufacturing and service sector, no statistically significant difference was found $(p>0.1)$.

\section{Conclusion}

This empirical research paper gives a systematic analysis of the stakeholder issue in relevant domestic and world literature, and provides quantitative key corporate stakeholder identification in the Republic of Serbia as an emerging economy. Stakeholders occupy an important position in the strategic business planning process. Since so far research on corporate stakeholders in Serbia is scarce, and does not provide enough data on this, for strategic business planning and strategic management important topic, the motivation for such a study determining the significance and role of certain corporate stakeholder groups for companies operating in Serbia has arisen. The obtained results show that, respectively, customers and owners keep leading positions among surveyed corporate stakeholders in Serbia, successively followed by suppliers, managers, government institutions, employees, investors, distributors, competitors, community as a whole, media, local community, vulnerable groups, and lastly, with the lowest significance, NGOs. Observing by economy sectors, service organizations proved to be the most sensitive to corporate stakeholders issue, and commercial organizations the least.

The scientific contribution of the conducted empirical research is reflected in identifying the importance of certain corporate stakeholder groups for companies operating in Serbia. The social contribution of the research refers to the possibilities of applying the obtained results in practice. The analysis of research results should serve as a guideline and assistance to the management of companies operating in the Republic of Serbia in creating successful business strategies, which should result in better positions on the Serbian market. Investigating this issue can show, and hence help Serbian managers, how to improve and/or redirect their strategic business decisions and subjects they are aimed at, thus increasing the potential for making better strategic business plans, developing better business strategies, which will secure better business performance results.

\section{REFERENCES}

[1] Babic, J. (2007). Društvena odgovornost korporacija. Sociološki pregled, 41(4), 445-471. DOI: $10.5937 /$ socpreg0704445B

[2] Brower, J. \& Mahajan, V. (2013). Driven to be good: a stakeholder theory perspective on the drivers of corporate social performance. Journal of Business Ethics, 117(2), 313-331. DOI: 10.1007/s10551-0121523-z

[3] Cohen L., Manion L. \& Morrison K. (2007). Research Methods in Education. London: Routledge.

[4] (2015). Suštinska pitanja koncepta društvene odgovornosti kompanija. Ekonomski pogledi, 17(1), 4959. DOI: 10.5937/EkoPog1501049C

[5] Digman, L. (1990). Strategic Management, Concepts, Decisions, Cases. Boston: BPI / IRWIN, Homewood.

[6] Djordjevic, M. (2010). Korporativne komunikacije i upravljanje odnosima sa stejkholderima. Marketing 41(3), 195-206.

[7] Evan, W. \& Freeman, R. (1993). A stakeholder theory of modern corporation: Kantian capitalism. In: Beauchamp, T. \& Bowie, N (eds.) Ethical theory and business (pp. 38-48). Upper Saddle River, NJ: Prentice Hall.

[8] Figar, N. \& Figar, V. (2011). Korporativna društvena odgovornost u kontekstu teorije stejkholdera. Facta universitatis - series: Economics and Organization, 8(1), 1-13.

[9] Freeman, R. E. (1984). Strategic management: A stakeholder approach. Boston, MA: Pitman.

[10] Freeman, R. E., Harrison, J. S., Wicks, A. C., Parmar, B. L., \& de Colle, S. (2010). Stakeholder theory: The state of the art. Cambridge: University Press.

[11] Griffin, R. \& Ebert, R. (1993). Business. New Jersey: Prentice-Hall International, Inc., Englewood Cliffs.

[12] Haksever, C., Chaganti, R. \& Cook, R. G. (2004). A model of value creation: strategic view. Journal of Business Ethics, 49(3), 295-307.

[13] Jovanovic, A. (2012).PR u kulturi kultura u PR-u. Kultura, 136, 325-339. DOI: 10.5937/kultura1236325J

[14] Jovanovic, B. \& Delibasic, B. (2014). Application of integrated QFD and fuzzy AHP approach in selection of suppliers. Management - časopis za teoriju i praksu menadžmenta, 19(72), 25-35. DOI: 10.7595/management.fon.2014.0018

[15] Jovanovic, D., Milenkovic, N., \& Dumonjic, B. (2017). Identifikacija stejkholdera - metode i pristupi. Vojno delo, 69(7), 384-395. DOI: 10.5937/vojdelo1707384J 
[16] Khomba, K., Kangaude-Ulaya, C. E. \& Hanif, R. (2013). Crafting a sustainable corporate performance: The value of corporate stakeholders. Australian Journal of Business and Management Research, 2(12), 20-27. DOI: 10.5430/jms.v4n3p94

[17] Kicosev, V., Radosavljevic, M., Kovacev, N. \& Djukic, S. (2011). Uloga analize zainteresovanih strana u održivom korišćenju budućih zaštićenih područja na primeru 'Rusande' i 'Okanj bare'. Zaštita prirode, 61(2), 129-146.

[18] Kim, J. H. \& Choi, I. (2019). Choosing the level of significance: A decision-theoretic approach. Abacus, in press. DOI: 10.1111/abac.12172

[19] Kim, J. H. (2020). Decision-theoretic hypothesis testing: A primer with R package OptSig. The American Statistician 74(4),370-379. DOI: 10.1080/00031305.2020.1750484

[20] Kontic, Lj. \& Kontic, J. (2010). Uključivanje korporativne društvene odgovornosti u strategiju banke. Bankarstvo, 39(3-4), 52-71.

[21] Krstic, B. (2014). Reputacija i finansijske performanse preduzeća. Facta universitatis - series: Economics and Organization, 11(1), 37-46.

[22] Krstic, N. \& Trbovich, A. (2015). Upravljanje zainteresovanim stranama u praksi društveno-odgovornog poslovanja u Srbiji. Ekonomika preduzeća, 63(5-6), 279-292. DOI: 10.5937/ekopre1506279K

[23] Krstic, N. (2014). Upravljanje stejkholderima iz poslovne perspektive. Megatrend revija, 11(2), 165-182.

[24] Lehtimaki, H. \& Kujala, J. (2015). Framing dynamically changing firm-stakeholder relationships in an international dispute over a foreign investment. A discursive analysis approach. Business Society, 56(3), 487-523. DOI: 10.1177/0007650315570611

[25] Losonc, A. N. (1997). Prevoznik/transportni subjekat u sklopu Stakeholder-menadžmenta. Privredna izgradnja, 40(1-2), 43-52.

[26] Metcalf, L \& Benn, S. (2012). The corporation is ailing social technology: Creating a "fit for purpose" design for sustainability. Journal of Business Ethics, 111, 195-210. DOI: 10.1007/s10551-012-1201-1

[27] Mihailovic, D. (2012). Metodologija naučnih istraživanja. Beograd: FON.

[28] Milicevic, V. (2014). Strategijsko poslovno planiranje - menadžment pristup. Beograd: FON

[29] Mitic, S. \& Ognjanov, G. (2013). Konkurentska prednost i korporativne komunikacije. Marketing, 44(4), 343-353. DOI: 10.5937/markt1304343M

[30] Mudge, J. F., Baker, L. F., Edge, C. B. \& Houlahan, J. E. (2012). Setting an optimal that minimizes errors in null hypothesis significance tests. PloS One, 7(2), e32734. DOI: 10.1371/journal.pone.0032734

[31] Nikolic, J. \& Eric, J. (2011).Uloga i vrste upravnih odbora u korporativnom upravljanju. Management časopis za teoriju i praksu menadžmenta, 16(60), 69-75.

[32] Petrovic, S. P. (2012). Pluralizam u strukturiranju upravljačkih problemskih situacija. Teme, 36(2), 797814.

[33] Phillips, R., Freeman, R.E. \& Wicks, A.C. (2003). What stakeholder theory is not. Business Ethics Quarterly, 13(4), 479-502. DOI: 10.5840/beq200313434

[34] Phillips, R.A. (1997). Stakeholder theory and a principle of fairness. Business Ethics Quarterly, 7(1), 5166. DOI: $10.2307 / 3857232$

[35] Popovic, A. (2010). Direktni marketing u neprofitnim organizacijama. Marketing, 41(3), 179-194.

[36] Post, J. E., Preston, L. E., \& Sachs, S. (2002). Redefining the corporation: Stakeholder management and organizational wealth. Stanford, CA: University Press.

[37] Predic, B. \& Ivanovic-Djukic, M. (2009). Društvena odgovornost preduzeća i steikholder menadžment. Management - časopis za teoriju i praksu menadžmenta, 14(51), 59-65.

[38] Prozesky, M. (2010). Ethics for accountants \& auditors. Cape Town: Oxford University Press.

[39] Purnell, L. S. \& Freeman, R. E. (2012). Stakeholder theory, fact/value dichotomy, and the normative core: how Wall Street stops the ethics conversation. Journal of Business Ethics, 109(1), 109-116. DOI: $10.1007 / \mathrm{s} 10551-012-1383-6$

[40] Rodic, I. (2012). Strategija Evropske unije za društveno odgovorno poslovanje. Pravo i privreda, 49(79), 610-629.

[41] Sachs, S. \& Maurer, M. (2009). Toward dynamic corporate stakeholder responsibility. J Bus Ethics, 85(3), 535-544. DOI: 10.1007/s10551-009-0213-y

[42] Scherer, A. G., \& Patzer, M. (2011). Where is the theory in stakeholder theory? A meta-analysis of the pluralism in stakeholder theory. In R. A. Phillips (Ed.), Stakeholder theory: Impact and prospects (pp. 140-162). Cheltenham: Edward Elgar.

[43] Schneider, T. \& Sachs, S. (2017). The Impact of Stakeholder Identities on Value Creation in Issue-Based Stakeholder Networks. Journal of Business Ethics, 144, 41-57. DOI: 10.1 007/s1055 1-01 5-2845-4

[44] Stovall, O.S., Neill, J.D. \& Perkins, D. (2004). Corporate governance, internal decision making, and the invisible hand. Journal of Business Ethics, 51, 221-227.

[45] Strand, R. \& Freeman, R. E. (2015). Scandinavian cooperative advantage: the theory and practice of stakeholder engagement in Scandinavia. Journal of Business Ethics, 127(1), 65-85. DOI: 10.1007/s10551013-1792-1 
[46] Terzic, A. (2016). Pristup umrežavanja aktera kao neophodan faktor razvoja kulturnog turizma u Srbiji. Kultura, 150, 254-270. DOI: 10.5937/kultura1650254T

[47] Vujicic, M. (2019). The role of tourism and the importance of the stakeholder approach in creating team building programs. Turizam, 23(3), 157-165. DOI: 10.5937/turizam23-23209

[48] Vujovic, S., Stefanovic, I. \& Vucurevic, S. (2009). Konfliktnost ciljeva kao problem korporativnog upravljanja sa aspekta stejkholder koncepta. Ekonomika poljoprivrede, 56(2), 265-273.

[49] Wasserstein, R. L. \& Lazar, N. A. (2016). The asa statement on p-values: Context, process, and purpose. The American Statistician, 70(2), 129-133. DOI: 10.1080/00031305.2016.1154108

Received: 2020-11-26

Revisions requested: 2021-02-15

Revised: 2021-03-11 (2 revisions)

Accepted: 2021-03-17

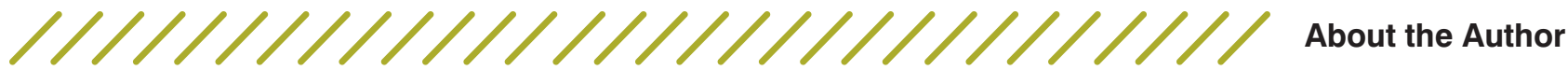

\section{Tanja Milić \\ University of Belgrade, Faculty of Organizational Sciences, Serbia tanja.milic@fon.bg.ac.rs}

Dr Tanja Milic is an Assistant Professor at the Faculty of Organizational Sciences, University of Belgrade. She is engaged in the courses within the Business Economics and Macroeconomics scientific field at undergraduate, specialist, and master studies. She is the author of a monograph, and the author or the co-author of scientific papers published in leading national and international journals and symposia. Her scientific work was awarded at the national level by the Belgrade Chamber of Economy.

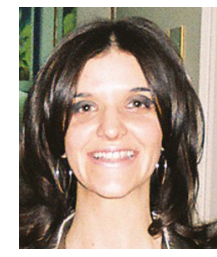

